Reference: Biol. Bull. 234: 139-151. (June 2018)

(C) 2018 The University of Chicago

\title{
Losing Reproduction: Effect of High Temperature on Female Biochemical Composition and Egg Quality in a Freshwater Crustacean with Direct Development, the Red Cherry Shrimp, Neocaridina davidi (Decapoda, Atyidae)
}

\author{
SOFÍA BALIÑA ${ }^{1}$, BRENDA TEMPERONI ${ }^{2,3}$, LAURA SUSANA LÓPEZ GRECO ${ }^{1}$, \\ AND CAROLINA TROPEA ${ }^{1, *}$ \\ ${ }^{1}$ Universidad de Buenos Aires, Consejo Nacional de Investigaciones Científicas y Técnicas (CONICET), \\ Instituto de Biodiversidad y Biología Experimental y Aplicada (IBBEA), Facultad de Ciencias Exactas \\ y Naturales, Departamento de Biodiversidad y Biología Experimental, Laboratorio de Biología de la \\ Reproducción y el Crecimiento de Crustáceos Decápodos, C1428EGA Buenos Aires, Argentina; ${ }^{2}$ Instituto de \\ Investigaciones Marinas y Costeras (IIMyC), Facultad de Ciencias Exactas y Naturales, Universidad \\ Nacional de Mar del Plata, CONICET, Rodríguez Peña 4046, B7602GSD Mar del Plata, Argentina; and \\ ${ }^{3}$ Instituto Nacional de Investigación y Desarrollo Pesquero (INIDEP), Paseo Victoria Ocampo No. 1, \\ B7602HSA Mar del Plata, Argentina
}

\begin{abstract}
Maternal provisioning is particularly important in invertebrates with abbreviated development because large energy reserves must be provided for the developing embryo. In this context, the objective of the present study was to analyze in an aquatic invertebrate with direct development the effect of temperature on female biochemical composition and reserve allocation to maturing ovaries, which determine egg quality. A decapod crustacean, the freshwater shrimp Neocaridina davidi, was used as experimental model. Newly hatched juveniles were exposed to $28{ }^{\circ} \mathrm{C}$ or $33^{\circ} \mathrm{C}$. Females showed mature ovaries and spawned at $28{ }^{\circ} \mathrm{C}$ (control ovigerous females), but no ovigerous female was found at $33^{\circ} \mathrm{C}$. After a 200-day period, half of the females at $33{ }^{\circ} \mathrm{C}$ were transferred to $28{ }^{\circ} \mathrm{C}$,

Received 17 August 2017; Accepted 2 April 2018; Published online 1 June 2018.

* To whom correspondence should be addressed. E-mail: carotropea@bg .fcen.uba.ar.

Abbreviations: CNO, control non-ovigerous female; $\mathrm{COF}$, control ovigerous female; DGC test, Di Rienzo, Guzmán, and Casanoves test; DHA, docosahexaenoic acid; EPA, eicosapentaenoic acid; FA, fatty acid; FAME, fatty acid methyl ester; GC, gas chromatography; HTNO, high-temperature non-ovigerous female; HUFA, highly unsaturated fatty acid; LIN, linoleic acid; MUFA, monounsaturated fatty acid; PCA, principal component analysis; PUFA, polyunsaturated fatty acid; SFA, saturated fatty acid; TOF, transferred ovigerous female.
\end{abstract}

where they rapidly showed mature ovaries and spawned (transferred ovigerous females). Ovigerous females and females that did not spawn at $28{ }^{\circ} \mathrm{C}$ (control non-ovigerous females) and at $33{ }^{\circ} \mathrm{C}$ (high-temperature non-ovigerous females) were sacrificed to determine their biochemical composition. The number, volume, weight, and biochemical composition of the eggs from transferred and control ovigerous females were also analyzed as indicators of their quality. Female biochemical composition was not influenced by temperature, because control and high-temperature non-ovigerous females had similar lipid, protein, and glycogen contents. However, ovarian maturation and spawning were inhibited at $33{ }^{\circ} \mathrm{C}$, which indicates a negative effect of this temperature on nutrient transfer to the oocytes. This effect was rapidly reversed after females were moved to $28{ }^{\circ} \mathrm{C}$; the eggs from control and transferred ovigerous females were of similar quality, except for a lower protein content in the latter. The present results provide valuable information on reserve allocation to reproduction under thermal stress.

\section{Introduction}

Ovarian maturation, which involves yolk synthesis and storage in the oocytes, is an energetically costly process, es- 
pecially in those species with abbreviated development, because large energy reserves must be provided for the developing embryo (Herring, 1974). Yolk is mainly composed of proteins, lipids, and carbohydrates. Proteins play a fundamental role as structural components of embryonic tissue and, under certain conditions, as fuel. Lipids are used by the developing embryo both as a substrate for energy metabolism and as structural components of cell membranes. Carbohydrates act as an energy source and are also essential for the synthesis of specific compounds, such as chitin (Gabbot and Bayne, 1973; Gardner, 2001; García Guerrero et al., 2003; Rosa et al., 2005; Dridi et al., 2007). The mobilization of these biochemical reserves to maturing oocytes may determine egg quality, which is related to the ability of an egg to undergo development (Holcomb et al., 2004). In this sense, several studies in marine and freshwater invertebrates have reported an association between egg lipid content and the percentage of fertile eggs, embryonic development, and hatching success (Helm et al., 1973; Besnard et al., 1988; Ruiz et al., 1992; Cahu et al., 1995; Wickins et al., 1995; Cavalli et al., 1999; Wouters et al., 1999; Martínez et al., 2000a).

One of the factors that may affect nutrient allocation to the ovary - and, ultimately, egg and larval quality - is the metabolic use and accumulation of proteins, lipids, and glycogen. Reserve mobilization from somatic tissues to the gonads has been reported for several mollusc species (Martínez et al., 2000b; Dridi et al., 2007) and crustacean species (Rosa and Nunes, 2003; Rodríguez González et al., 2006; Buckup et al., 2008). Indeed, shrimp females may transfer as much as $60 \%$ of their lipid reserves in the hepatopancreas to the maturing ovary (Herring, 1973; Palacios et al., 2000). Of particular significance are polyunsaturated fatty acids, which accumulate in the ovaries at advanced maturation stages (Harrison, 1990). The use of biochemical reserves has been shown to be positively correlated with water temperature in decapod crustaceans (Thomas et al., 2000; Stumpf and López Greco, 2015), scallops (Martínez et al., 2000a, b), and fish (Tidwell et al., 1999). As a consequence, high temperatures may also affect vitellogenesis and reproductive performance in aquatic invertebrates.

In a previous study on Neocaridina davidi (Bouvier, 1904), a caridean freshwater shrimp with direct development, Tropea et al. (2015) showed that females exposed to $32{ }^{\circ} \mathrm{C}$ had mature ovaries and spawned, but fertile eggs abnormally detached from female pleopods soon afterward (i.e., all the eggs were lost). However, eggs were able to complete the incubation period attached to pleopods (i.e., there was no egg loss) when females were exposed to $32{ }^{\circ} \mathrm{C}$ after reaching sexual maturity and spawning at $28{ }^{\circ} \mathrm{C}$ (Tropea et al., 2015). These results suggest a potentially stressful effect of high temperature on reserve mobilization to the ovary rather than on embryonic development. To our knowledge, no previous research has addressed this issue in aquatic invertebrates with direct de- velopment. Hence, the objective of the present study was to evaluate the effect of temperature on the biochemical composition of $N$. davidi females and on reserve allocation to maturing ovaries. We tested the hypothesis that a temperature higher than the optimum affects the accumulation of biochemical reserves in females and their transfer to maturing oocytes, which influences egg quality.

\section{Materials and Methods}

\section{Animals}

Juveniles of Neocaridina davidi (Bouvier, 1904) used in the present study were obtained from a reproductive stock provided by a commercial supplier (Acuamanus, Buenos Aires, Argentina). The stock was placed in plastic aquaria measuring $33.5 \mathrm{~cm} \times 25 \mathrm{~cm} \times 19 \mathrm{~cm}$, with 8 liters of dechlorinated tap water under continuous aeration $(\mathrm{pH} 7.5$, hardness $80 \mathrm{mg} \mathrm{l}^{-1}$ as $\mathrm{CaCO}_{3}$ equivalents) and at a constant temperature of $27^{\circ} \mathrm{C} \pm 1{ }^{\circ} \mathrm{C}$. The light/dark photoperiod was 14L : 10D. Each aquarium was provided with Java moss (Vesicularia sp.) as shelter. Shrimps were fed daily ad libitum commercial-balanced food for tropical fish (Tetracolor, Tetra, Melle, Germany), with the following approximate composition: minimum crude protein $47.5 \%$, minimum crude fat $6.5 \%$, maximum crude fiber $2.0 \%$, maximum moisture $6.0 \%$, minimum phosphorus $1.5 \%$, and minimum ascorbic acid $100 \mathrm{mg} \mathrm{kg}^{-1}$. The fatty acid profile of this diet is shown in Table 1 . The reproductive stock was visually inspected once daily to detect the presence of ovigerous females. When detected, they were placed in other plastic aquaria of $33.5 \mathrm{~cm} \times 25 \mathrm{~cm} \times 19 \mathrm{~cm}$, under the same experimental conditions as described above, until juveniles hatched.

\section{Experimental design}

Newly hatched juveniles were randomly assigned to plastic aquaria measuring $33.5 \mathrm{~cm} \times 25 \mathrm{~cm} \times 19 \mathrm{~cm}$, in one of the following treatments: control temperature: $28^{\circ} \mathrm{C} \pm 1{ }^{\circ} \mathrm{C}$, a temperature under which the species reaches an optimal combination of growth and reproduction rates under laboratory conditions (Tropea et al., 2015), and high temperature: $33{ }^{\circ} \mathrm{C} \pm 1{ }^{\circ} \mathrm{C}$.

Each aquarium was a replicate, and five replicates were used per treatment. In each aquarium, we placed 75 juveniles from 10 different females (938 shrimps $\mathrm{m}^{-2}$ ). Juveniles from each brood were equally represented in all replicates. They were maintained under the same conditions of water quality, photoperiod, and feeding, as described above, for the entire experimental period, which lasted 308 days. Once a week, all aquaria were cleaned, and water was completely replaced. From the day female ovaries became visible through the cephalothorax (around day 30 of the experimental period), aquaria 
Table 1

Fatty acid composition (mass percent of total fatty acids $\pm S E$ ) of Neocaridina davidi females maintained at $28^{\circ} \mathrm{C} \pm 1{ }^{\circ} \mathrm{C}$ from hatching to spawning (COF), females maintained at $33^{\circ} \mathrm{C} \pm 1{ }^{\circ} \mathrm{C}$ from hatching and transferred to $28^{\circ} \mathrm{C} \pm 1{ }^{\circ} \mathrm{C}$ after a 200-day period (TOF), recently spawned eggs from $\mathrm{COF}$, and the diet provided to shrimps during the experiment (Tetracolor)

\begin{tabular}{|c|c|c|c|c|c|c|c|}
\hline \multirow[b]{2}{*}{ Fatty acid } & \multicolumn{2}{|c|}{ Control ovigerous females (COFs) } & \multicolumn{2}{|c|}{ Transferred ovigerous females (TOFs) } & \multirow[b]{2}{*}{$\mathrm{COF}$} & \multirow[b]{2}{*}{ COF eggs } & \multirow[b]{2}{*}{ Diet (Tetracolor) } \\
\hline & Cephalothorax & Pleon & Cephalothorax & Pleon & & & \\
\hline $\mathrm{C} 10: 0$ & $0.44 \pm 0.05$ & $0.10 \pm 0.01$ & $0.24 \pm 0.05$ & $0.11 \pm 0.04$ & $0.27 \pm 0.06$ & $0.12 \pm 0.01$ & \\
\hline $\mathrm{C} 12: 0$ & $0.86 \pm 0.06$ & $0.28 \pm 0.03$ & $0.52 \pm 0.06$ & $0.18 \pm 0.01$ & $0.57 \pm 0.10$ & $0.13 \pm 0.00$ & $0.06 \pm 0.00$ \\
\hline $\mathrm{C} 14: 0$ & $1.51 \pm 0,26$ & $0.88 \pm 0.08$ & $1.19 \pm 0.26$ & $0.77 \pm 0.05$ & $1.20 \pm 0.16$ & $1.19 \pm 0.02$ & $1.88 \pm 0.02$ \\
\hline $\mathrm{C} 14: 1$ & $0.34 \pm 0.04$ & $0.18 \pm 0.02$ & $0.81 \pm 0.04$ & $0.31 \pm 0.04$ & $0.26 \pm 0.03$ & $0.68 \pm 0.03$ & $\ldots$ \\
\hline $\mathrm{C} 15: 0$ & $0.50 \pm 0.04$ & $0.47 \pm 0.01$ & $0.56 \pm 0.04$ & $0.57 \pm 0.01$ & $0.49 \pm 0.02$ & $0.54 \pm 0.01$ & $0.14 \pm 0.00$ \\
\hline $\mathrm{C} 15: 1$ & $0.12 \pm 0.01$ & $0.07 \pm 0.00$ & $0.11 \pm 0.01$ & $0.11 \pm 0.02$ & $0.10 \pm 0.01$ & $0.25 \pm 0.09$ & $\ldots$ \\
\hline $\mathrm{C} 16: 0$ & $18.89 \pm 0.82$ & $23.28 \pm 0.24$ & $17.13 \pm 0.82$ & $21.59 \pm 0.65$ & $21.08 \pm 0.83$ & $23.02 \pm 0.30$ & $15.18 \pm 0.00$ \\
\hline C16:1 & $2.12 \pm 0.19$ & $2.44 \pm 0.13$ & $2.53 \pm 0.19$ & $2.83 \pm 0.32$ & $2.28 \pm 0.12$ & $6.43 \pm 0.25$ & $2.70 \pm 0.04$ \\
\hline $\mathrm{C} 17: 0$ & $2.19 \pm 0.22$ & $1.61 \pm 0.10$ & $1.87 \pm 0.22$ & $1.61 \pm 0.01$ & $1.90 \pm 0.15$ & $0.60 \pm 0.03$ & $0.13 \pm 0.00$ \\
\hline $\mathrm{C} 17: 1$ & $1.97 \pm 0.17$ & $0.12 \pm 0.02$ & $1.25 \pm 0.17$ & $0.29 \pm 0.07$ & $1.04 \pm 0.32$ & $0.38 \pm 0.02$ & $0.33 \pm 0.00$ \\
\hline C18:0 & $4.70 \pm 0.12$ & $6.27 \pm 0.09$ & $4.90 \pm 0.12$ & $6.37 \pm 0.13$ & $5.48 \pm 0.27$ & $5.44 \pm 0.26$ & $2.47 \pm 0.01$ \\
\hline $\mathrm{C} 18: 1 \mathrm{n} 9 *$ & $13.16 \pm 0.24$ & $17.93 \pm 0.16$ & $13.17 \pm 0.24$ & $18.17 \pm 0.24$ & $15.55 \pm 0.81$ & $25.56 \pm 0.72$ & $23.38 \pm 0.00$ \\
\hline $\mathrm{C} 18: 1 \mathrm{n} 7$ & $3.28 \pm 0.10$ & $4.00 \pm 0.04$ & $3.63 \pm 0.10$ & $4.41 \pm 0.24$ & $3.64 \pm 0.13$ & $4.14 \pm 0.12$ & $1.62 \pm 0.01$ \\
\hline C18:1n11 & $0.12 \pm 0.01$ & $0.09 \pm 0.00$ & $0.13 \pm 0.01$ & $0.15 \pm 0.03$ & $0.11 \pm 0.01$ & $0.16 \pm 0.01$ & $\ldots$ \\
\hline C18:2n6* & $12.66 \pm 0.74$ & $14.13 \pm 0.35$ & $13.68 \pm 0.74$ & $14.98 \pm 0.47$ & $13.40 \pm 0.46$ & $20.89 \pm 0.71$ & $35.18 \pm 0.02$ \\
\hline $\mathrm{C} 18: 3 \mathrm{n} 6$ & $0.61 \pm 0.20$ & $0.66 \pm 0.02$ & $0.62 \pm 0.02$ & $0.71 \pm 0.06$ & $0.63 \pm 0.01$ & $1.24 \pm 0.04$ & $3.25 \pm 0.01$ \\
\hline $\mathrm{C} 18: 4 \mathrm{n} 3$ & $0.10 \pm 0.04$ & $0.04 \pm 0.01$ & $0.08 \pm 0.04$ & $0.09 \pm 0.00$ & $0.07 \pm 0.02$ & $0.11 \pm 0.00$ & $0.58 \pm 0.01$ \\
\hline $\mathrm{C} 20: 1$ & & $\ldots$ & $0.42 \pm 0.00$ & $\ldots$ & & $0.17 \pm 0.01$ & $0.18 \pm 0.00$ \\
\hline $\mathrm{C} 18: 3 \mathrm{n} 3$ & $0.38 \pm 0.08$ & $0.27 \pm 0.04$ & $0.23 \pm 0.08$ & $0.19 \pm 0.04$ & $0.32 \pm 0.05$ & $0.32 \pm 0.02$ & $0.80 \pm 0.00$ \\
\hline $\mathrm{C} 20: 0$ & & & & $\ldots$ & & & $0.06 \pm 0.00$ \\
\hline $\mathrm{C} 21: 0$ & $1.21 \pm 0.21$ & $0.95 \pm 0.12$ & $1.14 \pm 0.21$ & $0.85 \pm 0.03$ & $1.08 \pm 0.12$ & $0.29 \pm 0.04$ & $0.11 \pm 0.00$ \\
\hline $\mathrm{C} 22: 0$ & $7.12 \pm 0.57$ & $6.24 \pm 0.33$ & $8.85 \pm 0.57$ & $7.16 \pm 0.57$ & $6.68 \pm 0.34$ & $1.00 \pm 0.06$ & $0.40 \pm 0.01$ \\
\hline C20:3n6 & & & $\ldots$ & $\ldots$ & & $0.04 \pm 0.00$ & $0.19 \pm 0.00$ \\
\hline $\mathrm{C} 22: \ln 11$ & $0.21 \pm 0.03$ & $0.11 \pm 0.02$ & $0.77 \pm 0.03$ & $0.11 \pm 0.02$ & $0.16 \pm 0.02$ & $0.09 \pm 0.01$ & $0.27 \pm 0.01$ \\
\hline $\mathrm{C} 22: \ln 9$ & $13.83 \pm 0.97$ & $13.78 \pm 0.28$ & $14.20 \pm 0.97$ & $13.39 \pm 1.28$ & $13.81 \pm 0.48$ & $3.66 \pm 0.33$ & $\ldots$ \\
\hline $\mathrm{C} 24: 0$ & $\ldots$ & $\ldots$ & $\ldots$ & $\ldots$ & $\ldots$ & $0.11 \pm 0.01$ & $0.15 \pm 0.01$ \\
\hline $\mathrm{C} 20: 4 \mathrm{n} 6$ & $0.98 \pm 0.21$ & $0.37 \pm 0.06$ & $1.89 \pm 0.21$ & $0.62 \pm 0.11$ & $0.67 \pm 0.15$ & $\ldots$ & $0.18 \pm 0.03$ \\
\hline $\mathrm{C} 22: 5 \mathrm{n} 3$ & $\ldots$ & $\ldots$ & $\ldots$ & $\ldots$ & $\ldots$ & $\ldots$ & $0.70 \pm 0.01$ \\
\hline C20:5n3 (EPA) & $4.14 \pm 1.49$ & $2.11 \pm 0.44$ & $0.53 \pm 1.49$ & $0.40 \pm 0.12$ & $3.13 \pm 0.81$ & $0.38 \pm 0.02$ & $4.6 \pm 0.02$ \\
\hline C22:6n3 (DHA) & $8.55 \pm 0.15$ & $3.61 \pm 0.10$ & $9.56 \pm 0.15$ & $4.02 \pm 0.33$ & $6.08 \pm 0.83$ & $3.15 \pm 0.21$ & $4.53 \pm 0.00$ \\
\hline$\Sigma$ Saturated & $37.43 \pm 0.55$ & $40.08 \pm 0.25$ & $36.40 \pm 0.55$ & $39.21 \pm 0.41$ & $38.76 \pm 0.53$ & $32.45 \pm 0.51$ & $20.58 \pm 0.06$ \\
\hline$\Sigma$ Monounsaturated & $35.15 \pm 0.95$ & $38.73 \pm 0.27$ & $37.01 \pm 0.95$ & $39.78 \pm 0.45$ & $36.94 \pm 0.76$ & $41.52 \pm 0.45$ & $28.48 \pm 0.05$ \\
\hline$\Sigma$ Polyunsaturated & $13.66 \pm 0.68$ & $15.06 \pm 0.34$ & $14.53 \pm 0.68$ & $15.89 \pm 0.57$ & $14.36 \pm 0.43$ & $22.45 \pm 0.74$ & $39.42 \pm 0.03$ \\
\hline$\Sigma$ Highly unsaturated & $13.76 \pm 1.29$ & $6.13 \pm 0.41$ & $12.05 \pm 1.29$ & $5.12 \pm 0.37$ & $9.94 \pm 1.42$ & $3.63 \pm 0.21$ & $10.59 \pm 0.06$ \\
\hline$\Sigma \mathrm{n} 3$ & $13.16 \pm 1.56$ & $6.03 \pm 0.48$ & $10.40 \pm 1.56$ & $4.69 \pm 0.24$ & $9.60 \pm 1.42$ & $3.95 \pm 0.19$ & $6.68 \pm 0.04$ \\
\hline$\Sigma \mathrm{n} 6$ & $14.25 \pm 0.96$ & $15.16 \pm 0.40$ & $16.19 \pm 0.96$ & $16.32 \pm 0.52$ & $14.70 \pm 0.51$ & $22.17 \pm 0.75$ & $3.62 \pm 0.03$ \\
\hline $\mathrm{n} 3 / \mathrm{n} 6$ & $0.97 \pm 0.19$ & $0.40 \pm 0.04$ & $0.65 \pm 0.19$ & $0.29 \pm 0.01$ & $0.69 \pm 0.13$ & $0.18 \pm 0.00$ & $1.85 \pm 0.07$ \\
\hline DHA/EPA & $3.40 \pm 1.13$ & $2.66 \pm 1.20$ & $19.72 \pm 1.13$ & $12.50 \pm 4.00$ & $3.03 \pm 0.78$ & $8.51 \pm 0.82$ & $0.98 \pm 0.02$ \\
\hline
\end{tabular}

DHA, docosahexaenoic acid; EPA, eicosapentaenoic acid.

$*$ Cis and trans configurations.

were visually searched once a day for ovigerous females. No ovigerous females were observed at $33{ }^{\circ} \mathrm{C}$, even after a 200-day exposure period, which is 4 times the period previously reported for the species to reach sexual maturity at the optimum temperature (Tropea et al., 2015). Hence, at day 200 of the experiment, 10 females per replicate were transferred to 5 other aquaria set at $28^{\circ} \mathrm{C}$ (transfer treatment), along with males that had been maintained at the optimum temperature from hatching. The weight of these females ranged be- tween 60 and $70 \mathrm{mg}$, which is above the lowest weight reported at first spawning (Tropea et al., 2015; Fig. 1).

Once detected, ovigerous females reared at $28^{\circ} \mathrm{C}$ (control ovigerous females [COFs]) and those that had been transferred from $33{ }^{\circ} \mathrm{C}$ to $28{ }^{\circ} \mathrm{C}$ (transferred ovigerous females [TOFs]) were removed from the aquaria, and eggs were gently detached from their pleopods. The total number of eggs was recorded for each brood to calculate relative realized fecundity as number of eggs per brood per female weight. They were 


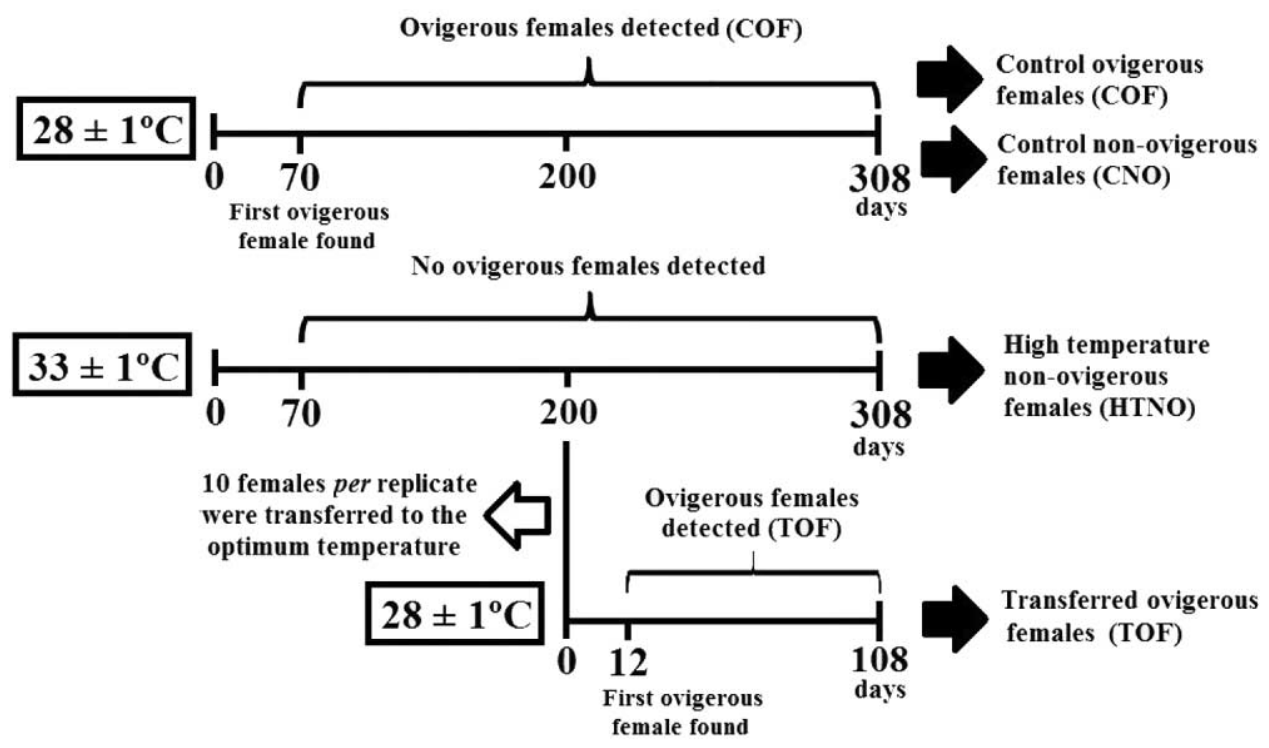

Figure 1. Scheme of the experimental design. Newly hatched juveniles of the freshwater shrimp Neocaridina davidi were randomly assigned to control $\left(28^{\circ} \mathrm{C} \pm 1{ }^{\circ} \mathrm{C}\right)$ or high temperature $\left(33^{\circ} \mathrm{C} \pm 1{ }^{\circ} \mathrm{C}\right)$ treatment. Ovigerous females were found in all replicates at $28^{\circ} \mathrm{C} \pm 1{ }^{\circ} \mathrm{C}(\mathrm{COFs})$ but not at $33^{\circ} \mathrm{C} \pm 1{ }^{\circ} \mathrm{C}$. After a 200-day period, $10 \mathrm{fe}$ males per replicate at $33{ }^{\circ} \mathrm{C} \pm 1{ }^{\circ} \mathrm{C}$ were transferred to the control temperature (TOFs). Ovigerous females were sacrificed following spawning. In addition, five non-ovigerous females per replicate at $28{ }^{\circ} \mathrm{C} \pm 1{ }^{\circ} \mathrm{C}(\mathrm{CNOs})$ and $33{ }^{\circ} \mathrm{C} \pm 1{ }^{\circ} \mathrm{C}$ (HTNOs) were sacrificed after reaching a weight of $50 \mathrm{mg}$. The experimental groups obtained at each temperature treatment are shown at the right of the scheme. The experimental period lasted 308 days.

then weighed (wet weight, precision $0.1 \mathrm{mg}$ ), and $30 \%$ of the eggs from each brood were measured along the major and minor axes using a stereomicroscope. Egg volume was calculated using the formula for an ellipsoid: $4 / 3 \times r 1 \times r 2 \times r 2$, where $r 1$ and $r 2$ are the radii of the major and minor axes, respectively (Clarke, 1993). A mean value of egg weight and volume was calculated for all the broods obtained in each aquarium. Finally, the eggs were stored at $-70{ }^{\circ} \mathrm{C}$ for biochemical analyses.

Following egg removal, females were weighed (wet weight, precision $0.1 \mathrm{mg}$ ) and sacrificed after being coldanesthetized at $-20{ }^{\circ} \mathrm{C}$ for $15 \mathrm{~min}$. The cephalothorax of each female was detached from the pleon, and both were weighed (wet weight, precision $0.1 \mathrm{mg}$ ) and stored at $-70{ }^{\circ} \mathrm{C}$ for biochemical analyses. Some nutrients are differentially deposited in the body: lipids are mainly stored in the hepatopancreas, which is located in the cephalothorax, while proteins are mainly stored in the muscle, which is mostly located in the pleon. Hence, the cephalothorax and pleon of females were analyzed separately to determine whether they consume lipids, proteins, and glycogen from a specific body part during vitellogenesis.

In addition to the procedure described above, 5 females with a weight above $50 \mathrm{mg}$ that never spawned throughout the experimental period were removed from each replicate set at $28{ }^{\circ} \mathrm{C}$ (control non-ovigerous females [CNOs]) and $33{ }^{\circ} \mathrm{C}$ (high-temperature non-ovigerous females [HTNOs]).
They were sacrificed, and the pleon and cephalothorax of each female were weighed and stored as previously described for ovigerous females (Fig. 1).

\section{Biochemical analyses}

Protein, lipid, and glycogen concentrations (expressed in $\mu \mathrm{g} \mathrm{mg}^{-1}$ ) were determined spectrophotometrically in homogenates of eggs, pleons, and cephalothoraxes from all females of a replicate (i.e., aquarium), according to the methods described by Bradford (1976), Folch et al. (1957), and Van Handel (1965), respectively, and modified for the species by Tropea et al. (2015). In general, five replicates were used for biochemical determinations, except in some cases in which two (for CNO pleon and cephalothorax samples) or three (for TOF egg samples) of the five original replicates had to be grouped together in order to reach the minimum mass required for biochemical protocols. In those cases, three and four replicates were used, respectively. Calculations were performed on a wet weight basis.

For protein determination, samples weighing 15-25 mg were homogenized in $4: 1$ volume: weight of $50 \mathrm{mmol}^{-1}$ Tris- $\mathrm{HCl}$ buffer, $\mathrm{pH} 7.5$, and centrifuged at $10,000 \times g$ for $30 \mathrm{~min}$ in a refrigerated centrifuge $\left(4^{\circ} \mathrm{C}\right)$. Total proteins were estimated in the supernatant by the Coomassie blue dye method, with bovine serum albumin as standard (concentra- 
tion $1 \mathrm{mg} \mathrm{ml}^{-1}$ ). Absorbance was read at $595 \mathrm{~nm}$. For lipid determination, samples weighing 60-75 mg were homogenized in 20:1 volume:weight of a mixture of chloroform and methanol $(2: 1, \mathrm{v} / \mathrm{v})$, then mixed with $0.9 \% \mathrm{NaCl}$ and centrifuged to separate the lipid fraction. Total lipids were quantified by the sulfo-phospho-vanillin method, with extra virgin olive oil diluted with absolute ethanol as standard (concentrations $5 \mathrm{mg} \mathrm{ml}^{-1}$ for egg analysis and $1 \mathrm{mg} \mathrm{ml}^{-1}$ for pleon and cephalothorax analyses). Absorbance was read at $530 \mathrm{~nm}$. For glycogen determination, samples weighing 25$35 \mathrm{mg}$ were boiled with 4:1 volume: weight of $\mathrm{KOH} 30 \%$ during $30 \mathrm{~min}$ for egg samples and $60 \mathrm{~min}$ for pleon and cephalothorax samples. After cooling, $75 \mathrm{ml}$ of saturated $\mathrm{Na}_{2} \mathrm{SO}_{4}$ and $1875 \mathrm{ml}$ of absolute ethanol were added to each sample, and glycogen was precipitated with centrifugation at $2000 \times$ $g$ for $10 \mathrm{~min}$. The precipitate was then dissolved in $250 \mu \mathrm{l}$ of distilled water, and glycogen was measured by the anthrone-reagent method. Rabbit liver (Fluka, Sigma-Aldrich, St. Louis, MO) was used as standard (concentration $1 \mathrm{mg} \mathrm{ml}^{-1}$ ), and absorbance was read at $620 \mathrm{~nm}$. The total energy content (expressed in $\mathrm{J} \mathrm{mg}^{-1}$ ) of each egg, pleon, and cephalothorax sample was calculated from its biochemical composition, using the following conversion factors: $23.42 \mathrm{~J} \mathrm{mg}^{-1}$ for proteins, $39.31 \mathrm{~J} \mathrm{mg}^{-1}$ for lipids, and $17.14 \mathrm{~J} \mathrm{mg}^{-1}$ for carbohydrates (Winberg, 1971).

Fatty acids (FAs) were determined in homogenates of pleons and cephalothoraxes from all ovigerous females (COFs and TOFs) of a replicate and in homogenates of COF eggs using gas chromatography (GC) after FA transesterification to fatty acid methyl esters (FAMEs). Procedures for FA methylation were based on those described by Dowd (2012), with some modifications. Briefly, lipid samples weighing $60 \mathrm{mg}$ were vigorously mixed for 1 min with $2 \mathrm{ml}$ of hexane and $0.3 \mathrm{ml}$ of a mixture of $\mathrm{KOH}$ and $\mathrm{MeOH}$. They were mixed again for another minute after the addition of $2 \mathrm{ml}$ of $\mathrm{NaCl}$ and $2 \mathrm{ml}$ of hexane. Samples were allowed to stand for $5 \mathrm{~min}$, and then the upper hexane layer was removed and transferred to a clean tube. Fatty acid methyl esters were determined using a gas chromatograph (Shimadzu GC-2010, Koyoto, Japan) equipped with a flame ionization detector $\left(260^{\circ} \mathrm{C}\right)$ and capillary column (30 m $\times 0.32 \mathrm{~mm}$; $0.25 \mu \mathrm{m}$ film thickness; Omegawax 320, Sigma-Adrich). Gas chromatography parameters were set as follows: split rate 50 , injector temperature $250{ }^{\circ} \mathrm{C}$, column temperature $120^{\circ} \mathrm{C}$, and carrier gas nitrogen. The oven temperature was increased to $240{ }^{\circ} \mathrm{C}$ at a rate of $5{ }^{\circ} \mathrm{C} \mathrm{min}-1$ and held for $5 \mathrm{~min}$. A sample volume of $1 \mu \mathrm{l}$ was manually injected in duplicate, and FA peaks were identified by comparison of their retention times with those of external reference standards (Supelco FAME Mix C4-C24 + PUFA No. 1 Marine Source, Sigma-Aldrich). Retention times and peak areas were processed by Shimadzu GC Solution software. The relative amount of each FA in the sample is expressed as the percentage of individual peak areas relative to the sum of all FA peak areas.

\section{Statistical analyses}

The relative realized fecundity, weight, volume, biochemical composition, and energy content of eggs were compared between COFs and TOFs using one-way ANOVA. The biochemical composition and energy content of female pleons and cephalothoraxes were analyzed with two-way ANOVA. "Temperature combined with female reproductive condition" was one fixed factor with four levels (COF, TOF, CNO, and HTNO), while "part of female body" was the other fixed factor with two levels (pleon and cephalothorax). General linear mixed-effect models were used for those variables that did not meet the assumption of homoscedasticity. In all cases, the Di Rienzo, Guzmán, and Casanoves (DGC) test was applied when significant differences were found. A principal component analysis (PCA) was used to determine the differences in FA composition between COF pleon, COF cephalothorax, TOF pleon, and TOF cephalothorax, and between COFs and their eggs, with the software Past 2.17c (Hammer et al., 2001). The outcome was plotted in two dimensions, with principal components (PC1, PC2) explaining the most variation. Results are presented as mean \pm standard error. All tests were carried out at the 95\% significance level, with Infostat 2016 software (Infostat Group, Facultad de Ciencias Agropecuarias, Universidad Nacional de Córdoba, Córdoba, Argentina) (Di Rienzo et al., 2002).

\section{Results}

\section{Egg quality}

No significant differences were observed in relative realized fecundity $\left(F_{1,8}=0.69, P=0.430\right)$ and egg volume $\left(F_{1,8}=\right.$ $3.09, P=0.117)$ between COFs and TOFs. Mean values were $0.50 \pm 0.01$ eggs per brood $\mathrm{mg}$ female ${ }^{-1}$ and $0.25 \pm 0.01 \mathrm{~mm}^{3}$ for COFs and $0.53 \pm 0.04$ eggs per brood $\mathrm{mg} \mathrm{female}^{-1}$ and $0.26 \pm 0.01 \mathrm{~mm}^{3}$ for TOFs. Wet weight was significantly higher $\left(F_{1,8}=8.87, P=0.018\right)$ in eggs from TOFs than in those from COFs (Fig. 2). Biochemical composition analyses showed no differences in glycogen $\left(F_{1,6}=1.69, P=0.251\right.$; means $3.37 \pm 0.24 \mu \mathrm{g} \mathrm{mg}^{-1}$ for COF eggs and $2.77 \pm 0.39 \mu \mathrm{g} \mathrm{mg}^{-1}$ for TOF eggs) and lipid $\left(F_{1,6}=4.80 \times 10^{-4}, P=0.983\right.$; means $66.11 \pm 6.76 \mu \mathrm{g} \mathrm{mg}^{-1}$ for COF eggs and $65.87 \pm 8.73 \mu \mathrm{g} \mathrm{mg}^{-1}$ for TOF eggs) contents between COF and TOF eggs, but protein content was significantly lower $\left(F_{1,6}=42.37, P=0.000\right)$ in the latter. In all cases, lipid was the major biochemical component, followed by proteins and glycogen. No differences $\left(F_{1,5}=0.03, P=0.876\right)$ were found in total energy content between eggs from both experimental groups; mean values were $2.84 \pm 0.30 \mathrm{~J} \mathrm{mg}^{-1}$ for COF eggs and $2.75 \pm 0.48 \mathrm{~J} \mathrm{mg}^{-1}$ for TOF eggs (Fig. 3).

\section{Female biochemical composition}

Because the interaction between factors was not significant in the statistical analysis of lipid $\left(F_{3,30}=1.14, P=\right.$ 


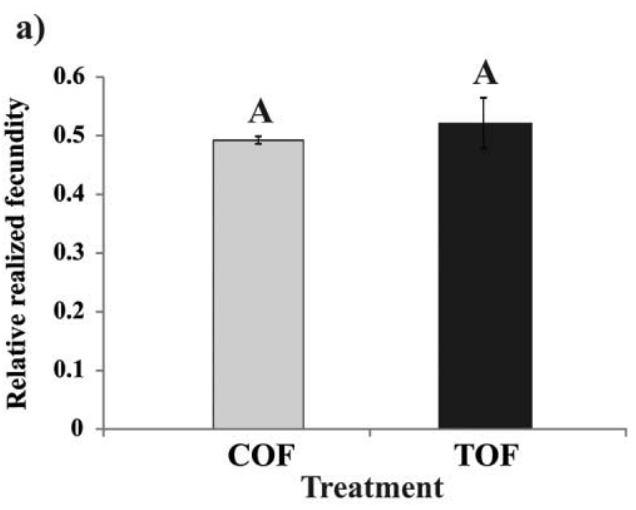

b)

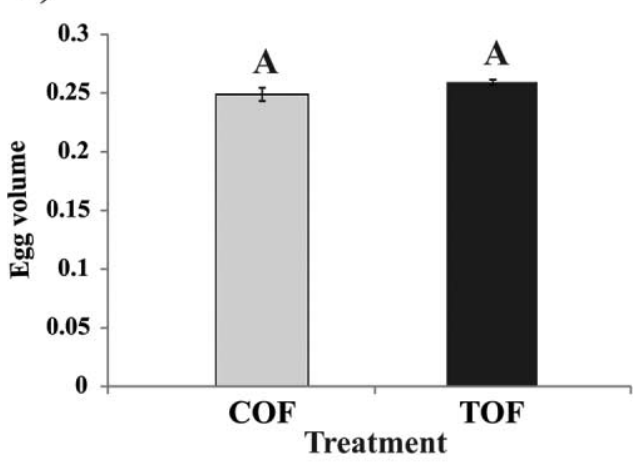

c)

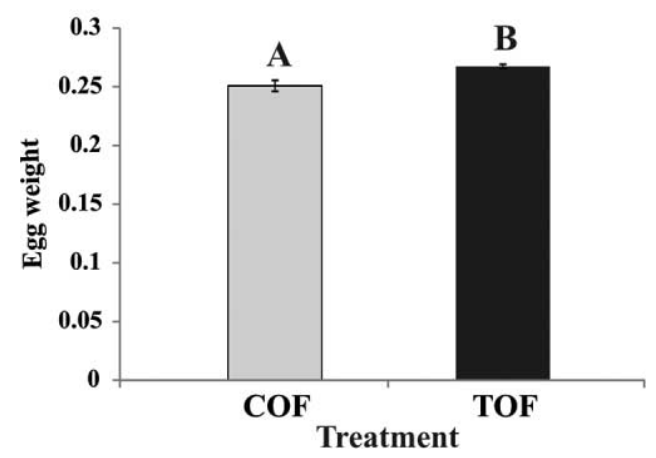

Figure 2. Relative realized fecundity (eggs per brood $\mathrm{mg}$ female ${ }^{-1}$ ), egg volume $\left(\mathrm{mm}^{3}\right)$, and egg weight $(\mathrm{mg})$ for Neocaridina davidi females. The number (a), volume (b), and weight (c) of eggs (mean $\pm \mathrm{SE}$ ) from females maintained at $28{ }^{\circ} \mathrm{C} \pm 1{ }^{\circ} \mathrm{C}$ from hatching to spawning (COFs) and females maintained at $33{ }^{\circ} \mathrm{C} \pm 1{ }^{\circ} \mathrm{C}$ from hatching and transferred to $28{ }^{\circ} \mathrm{C} \pm$ $1{ }^{\circ} \mathrm{C}$ after a 200-day period (TOFs) were determined immediately after being spawned. Different capital letters above bars indicate statistically significant differences between the two experimental groups $(P<0.05)$. COF, control ovigerous female; TOF, transferred ovigerous female.

$0.349)$, protein $\left(F_{3,28}=2.43, P=0.086\right)$, and glycogen $\left(F_{3,27}=1.87, P=0.159\right)$ contents in females, each was analyzed separately. Lipid concentration was significantly higher $\left(F_{3,30}=6.53, P=0.002\right.$; DGC test, $\left.P<0.05\right)$ in CNOs, HTNOs, and TOFs as compared to COFs. Protein concentration was highest in non-ovigerous females (CNOs and HTNOs), intermediate in TOFs, and lowest in COFs $\left(F_{3,28}=18.87\right.$, $P=0.000$; DGC test, $P<0.05)$. Glycogen concentration was highest in non-ovigerous females (CNOs and HTNOs) and lowest in ovigerous females (COFs and TOFs) $\left(F_{3,27}=\right.$ $16.28, P=0.000$; DGC test, $P<0.05)$. These results were independent of female body part (cephalothorax and pleon). On the other hand, female cephalothoraxes had a significantly higher $\left(F_{1,30}=3.98, P=0.045\right)$ lipid content than pleons, independent of female reproductive condition and exposure temperature. No statistical differences were found in protein $\left(F_{1,28}=0.09, P=0.771\right)$ and glycogen $\left(F_{1,27}=1.24, P=\right.$ $0.275)$ contents between female pleons and cephalothoraxes (Fig. 4).

Because the interaction between factors was statistically significant $\left(F_{3,25}=5.02, P=0.007\right)$ in the analysis of female energy content, they were analyzed together. The pleon had energy content similar to that of the cephalothorax in COFs, TOFs, and HTNOs (DGC test, $P<0.05$ ). However, this variable was significantly higher in the pleon than in the cephalothorax in CNOs (DGC test, $P<0.05$ ). On the other hand, the comparison between experimental groups showed that pleon energy content was highest in CNOs, lowest in COFs, and intermediate in TOFs and HTNOs (DGC test, $P<0.05)$. Cephalothorax energy content showed the highest values in HTNOs and similar values among COFs, TOFs, and CNOs (DGC test, $P<0.05$ ) (Fig. 5).

\section{Fatty acid profiles}

Table 1 shows the FA profiles of COF and TOF pleons and cephalothoraxes and of COF eggs. In all cases, there was a higher proportion of saturated (SFAs) and monounsaturated (MUFAs) fatty acids than polyunsaturated (PUFAs) and highly unsaturated (HUFAs) fatty acids. The main FAs in females and eggs were palmitic acid (C16:0), oleic acid (C18:1n9), and linoleic acid (LIN, C18:2n6); erucic acid (C22:1n9) was also predominant in females. The percentage of C18:0, C22:0, eicosapentaenoic acid (EPA, C20:5n3), and docosahexaenoic acid (DHA, C22:6n3) was intermediate in females.

A PCA biplot of FA profile data showed a distinction between COF pleon, COF cephalothorax, TOF pleon, and TOF cephalothorax. PC1 and PC2 explained $84.6 \%$ and $14.7 \%$ of total variation in data, respectively. Considering loadings above 0.5 , palmitic acid, oleic acid, and DHA contributed the most to group differentiation along PC1. Pleons had more palmitic and oleic acids than cephalothoraxes, while the latter had more DHA than the former, both in COFs and in TOFs. On the other hand, EPA was responsible for group differentiation along PC2, with COFs having more EPA than TOFs, both in the pleon and in the cephalothorax (Table 2; Fig. 6).

Regarding COFs and their eggs, most SFAs were more abundant in females than in eggs, while the opposite pattern was observed for MUFAs. Within PUFAs, the percentage of LIN was higher in eggs than in females. All the HUFAs detected (EPA and DHA) were much higher in COFs than in their eggs (Table 1). A PCA biplot of FA profile data showed 
a)

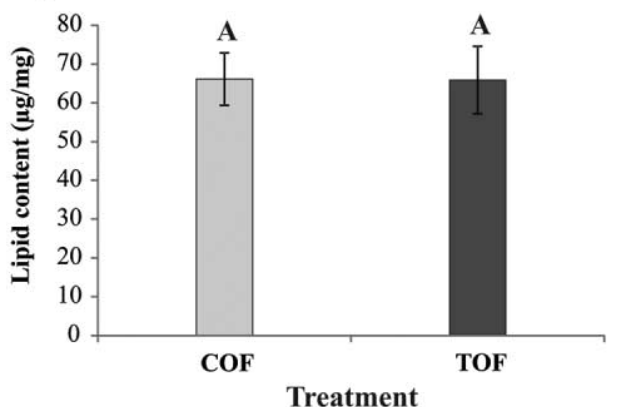

b)

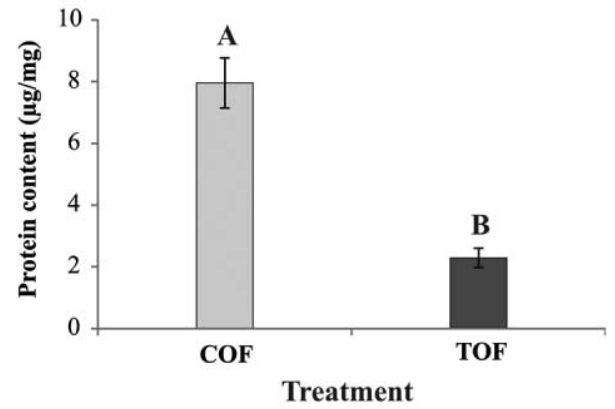

c)

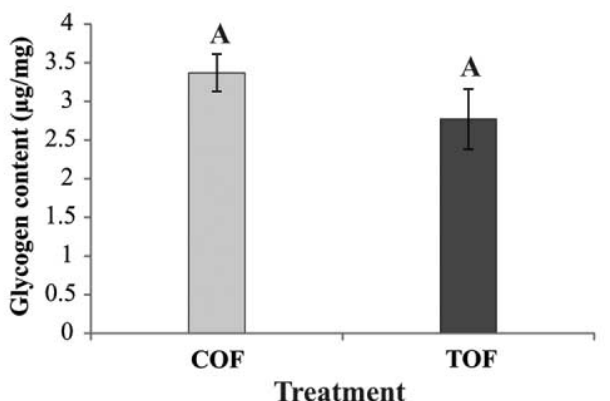

d)

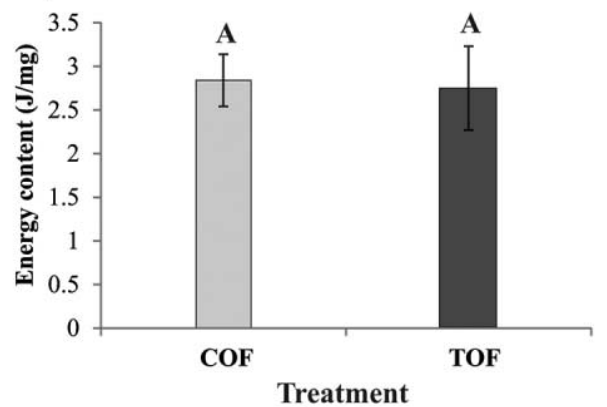

Figure 3. Biochemical composition and energy content of eggs from Neocaridina davidi females. Lipid (a), protein (b), glycogen (c), and energy (d) contents (mean \pm SE) were determined in newly spawned eggs from females maintained at $28{ }^{\circ} \mathrm{C} \pm 1{ }^{\circ} \mathrm{C}$ from hatching to spawning (COFs) and females maintained at $33{ }^{\circ} \mathrm{C} \pm 1{ }^{\circ} \mathrm{C}$ from hatching and transferred to $28^{\circ} \mathrm{C} \pm 1{ }^{\circ} \mathrm{C}$ after a 200-day period (TOFs). Different capital letters above bars indicate statistically significant differences between the two experimental groups $(P<0.05)$. COF, control ovigerous female; TOF, transferred origerous female.

a distinction between $\mathrm{COF}$ pleon, COF cephalothorax, and COF eggs. PC1 and PC2 explained $90.6 \%$ and $9.5 \%$ of total variation in data, respectively. Considering loadings above 0.5 , oleic and erucic acids were the most important FAs for group differentiation along PC1. Oleic acid was more abundant in eggs, and erucic acid was more abundant in COFs. On the other hand, palmitic acid and DHA were the most important FAs for group differentiation along PC2. COF pleons had more palmitic and erucic acids, while COF cephalothoraxes had more DHA (Table 2; Fig. 7).

\section{Discussion}

The objective of the present study was to evaluate the effect of temperature on the biochemical composition of Neocaridina davidi females and on reserve allocation to maturing oocytes, which determine egg quality. Ovarian maturation and spawning were observed in females at control temperature $\left(28^{\circ} \mathrm{C}\right)$ but not in those at high temperature $\left(33^{\circ} \mathrm{C}\right)$, indicating a clear effect of the latter on nutrient transfer to the ovary. The present results partially differ from those previously reported by Tropea et al. (2015), who found ovigerous females at the highest temperature tested $\left(32^{\circ} \mathrm{C}\right)$, though in a lower proportion than at $28{ }^{\circ} \mathrm{C}(14 \%$ vs. $100 \%)$. The high temperature applied in our study and that by Tropea et al. (2015) differed by only one degree, a small but significant difference, given the respective findings. It is possible that $33{ }^{\circ} \mathrm{C}$ accentuated the already observed trend toward the inhibition of ovarian maturation and spawning at $32{ }^{\circ} \mathrm{C}$. In this context, the small difference in high temperatures seems to be responsible for the transition from low spawning probability to no spawning at all. However, we cannot discard other possible causes for the different results obtained in our study and that by Tropea et al. (2015), such as the distinct source of experimental shrimps, because they were provided by different commercial suppliers. It is known that some genotypes are less influenced than others by environmental stress $(\mathrm{Ca}-$ low, 1989).

Ovarian maturation involves the mobilization and accumulation of organic reserves in the ovary, previously stored in other organs, such as the hepatopancreas in crustaceans (Palacios et al., 2000; Cavalli et al., 2001) and the digestive gland and adductor muscle in bivalves (Gabbot and Bayne, 1973; Martínez et al., 2000b; Dridi et al., 2007). It seems from our results that the higher energy demand resulting from metabolic rate increase with temperature (Reynolds, 2002) led to the accumulation of insufficient reserves for ovarian maturation and spawning. The exposure of the scallop Argo- 
a)

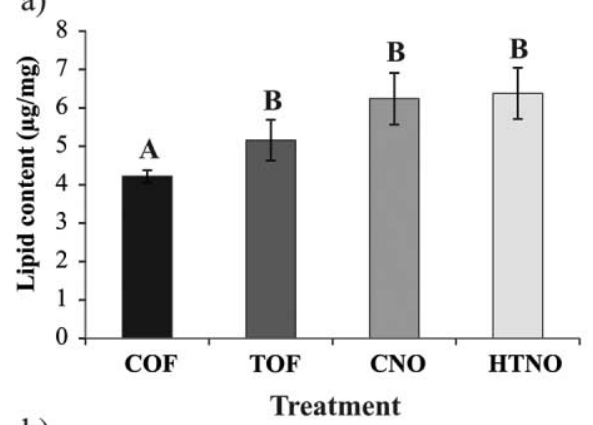

b)

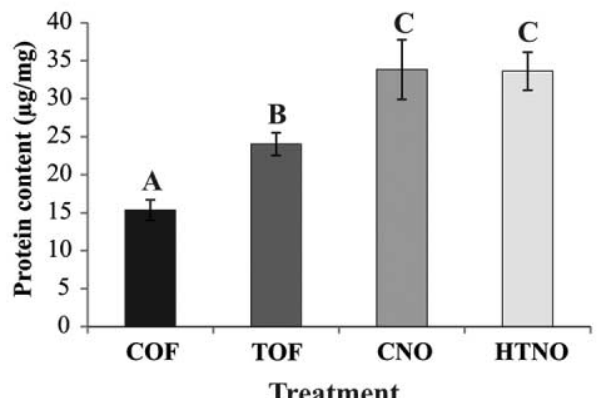

c)

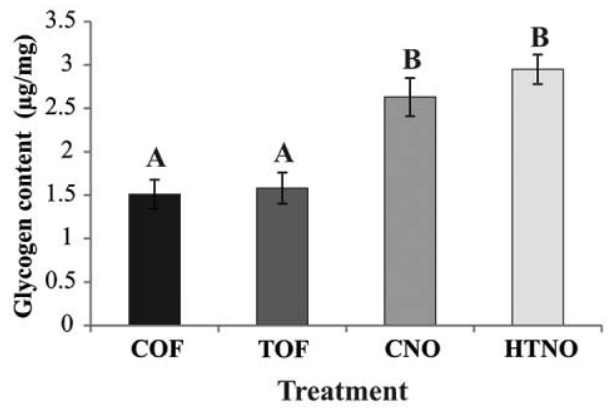

d)

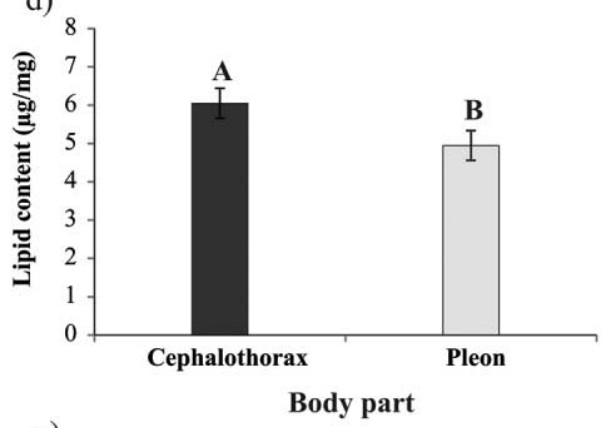

e)
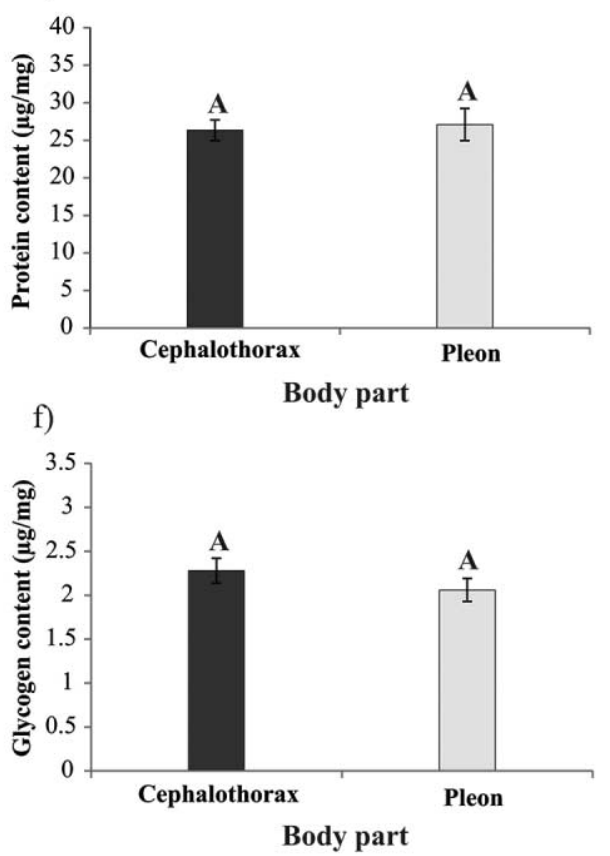

Figure 4. Biochemical composition of Neocaridina davidi females. Lipid (a, d), protein (b, e), and glycogen (c, f) contents (mean $\pm \mathrm{SE}$ ) were determined in the pleon and cephalothorax of females maintained at $28{ }^{\circ} \mathrm{C} \pm 1{ }^{\circ} \mathrm{C}$ from hatching to spawning (COFs), females maintained at $33^{\circ} \mathrm{C} \pm 1{ }^{\circ} \mathrm{C}$ from hatching and transferred to $28^{\circ} \mathrm{C} \pm 1{ }^{\circ} \mathrm{C}$ after a 200-day period (TOFs), non-ovigerous females maintained at $28^{\circ} \mathrm{C} \pm 1{ }^{\circ} \mathrm{C}$ from hatching (CNOs), and non-ovigerous females maintained at $33{ }^{\circ} \mathrm{C} \pm 1{ }^{\circ} \mathrm{C}$ from hatching (HTNOs). Females were sacrificed immediately after spawning (COFs and TOFs) or after reaching a weight of $50 \mathrm{mg}$ (CNOs and HTNOs). Different capital letters above bars indicate statistically significant differences among the experimental groups, averaging pleon and cephalothorax values (a, b, c), and between female body parts, averaging COF, TOF, CNO, and HTNO values (d, e, f) $(P<0.05)$. CNO, control non-ovigerous female; COF, control ovigerous female; HTNO, high-temperature non-ovigerous female; TOF, transferred ovigerous female.

pecten purpuratus to high temperatures likely led to the depletion of muscle reserves and a lower content of biochemical compounds in the gonad (Martínez et al., 2000a, b). However, the comparison in our study between CNOs and HTNOs showed that female biochemical composition was not affected by high temperature, because both groups had similar lipid, protein, and glycogen contents. Altogether, the present results show that the difference between the two temperatures tested was large enough to affect nutrient allocation to the ovary but not reserve storage in female tissues other than the ovary. In other words, high temperature inhibited reproduction with- out affecting the storage of biochemical reserves in females, which were able to cover their metabolic demands and even grow. The high-protein diet provided to females may have allowed them to obtain all protein requirements from food, with no need to consume internal reserves despite their accelerated metabolism.

Although reproduction is particularly costly in crustacean species with abbreviated development (Herring, 1974), few studies have addressed its impact on female biochemical composition (e.g., Buckup et al., 2008; Tropea and López Greco, 2015), and no distinct analysis for female hepatopancreas and 
a)

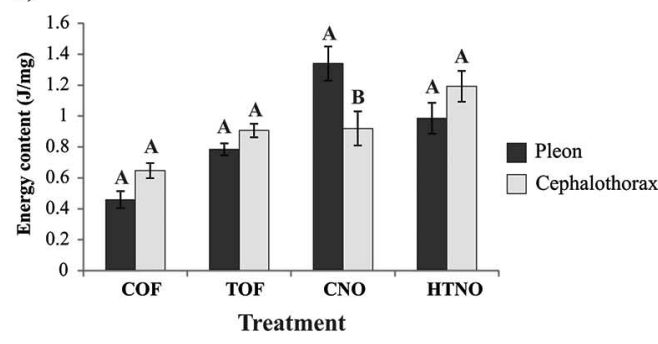

b)

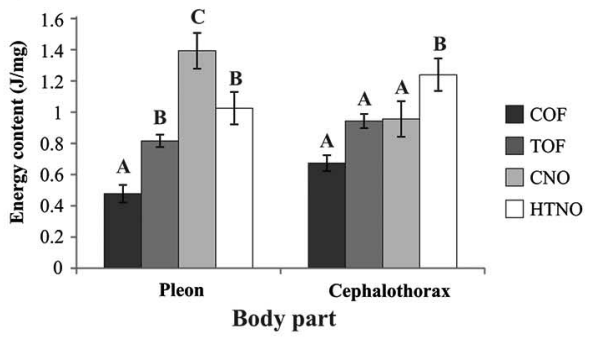

Figure 5. Energy content of Neocaridina davidi females. The energy content (mean $\pm \mathrm{SE}$ ) was calculated for the pleon and cephalothorax of females maintained at $28{ }^{\circ} \mathrm{C} \pm 1{ }^{\circ} \mathrm{C}$ from hatching to spawning (COFs), females maintained at $33{ }^{\circ} \mathrm{C} \pm 1{ }^{\circ} \mathrm{C}$ from hatching and transferred to $28{ }^{\circ} \mathrm{C} \pm 1{ }^{\circ} \mathrm{C}$ after a 200-day period (TOFs), nonovigerous females maintained at $28{ }^{\circ} \mathrm{C} \pm 1{ }^{\circ} \mathrm{C}$ from hatching (CNOs), and non-ovigerous females maintained at $33^{\circ} \mathrm{C} \pm 1{ }^{\circ} \mathrm{C}$ from hatching (HTNOs). Different capital letters above bars indicate statistically significant differences between female body parts for each experimental group (a) and among experimental groups for each female body part (b) $(P<0.05)$. CNO, control non-ovigerous female; COF, control ovigerous female; HTNO, hightemperature non-ovigerous female; TOF, transferred ovigerous female.

muscle (the main sites of lipid and protein storage, respectively) has yet been reported in caridean shrimps. The present results show a clear impact of reproduction on the biochemical composition of females, as evidenced by the lower lipid, protein, and glycogen contents in ovigerous females at $28^{\circ} \mathrm{C}$ than in non-ovigerous ones. This was true for both the cephalothorax and the pleon of experimental females. Tropea and López Greco (2015) have already shown a decrease in lipid and energy contents in reproductive females as compared to virgin females; however, in that study, biochemical composition was determined in whole animals. Even though lipids are mainly stored in the hepatopancreas, which is located in the cephalothorax (Vogt et al., 1985; Muriana et al., 1993; García et al., 2002), and proteins are stored in the muscle, which is mostly located in the pleon (Rosa and Nunes, 2003), the present results show for the first time that the lipids and proteins used by females for vitellogenesis come from both body parts.

Some physiological processes, such as growth, storage, or reproduction, cease if the available energy flux covers only basal maintenance costs, but they resume under more favorable conditions (Kooijman, 2010). In the present study, a fast "recovery" of female reproductive physiology was observed after the transfer of females from $33^{\circ} \mathrm{C}$ to $28^{\circ} \mathrm{C}$; some of them showed mature ovaries and even spawned after only 9 days at this temperature. Moreover, higher protein and lipid contents were found in TOFs in comparison to COFs. Taking into account that TOF eggs had a lower protein concentration than COF eggs, it is probable that the higher protein content in TOFs resulted from a lower protein transfer to the ovary. Proteins have been found to act as an energy source during prolonged stressful situations (Anger, 2001). On this basis, females exposed to high temperature for so long (200 days) may have "prioritized" the accumulation of protein reserves for themselves over their transfer to maturing oocytes, even after being moved to an optimum water temperature. On the other hand, TOFs had higher lipid content than COFs, al- though they allocated the same amount of total lipids to the ovary, as shown by the similar lipid concentration in eggs from both female groups. These results suggest that TOFs accumulated more lipid reserves than COFs before being transferred to $28{ }^{\circ} \mathrm{C}$ and spawning. However, the fact that nonovigerous females at $33{ }^{\circ} \mathrm{C}$ had the same lipid content as non-ovigerous females at $28^{\circ} \mathrm{C}$ indicates that the difference in lipid content between TOFs and COFs may have arisen in the interval between female transfer to $28{ }^{\circ} \mathrm{C}$ and spawning. It is possible that the metabolic rate of females decreased when they were moved from $33{ }^{\circ} \mathrm{C}$ to $28{ }^{\circ} \mathrm{C}$ (Childress et al., 1990), leading to a higher energetic efficiency caused by lower metabolic expenditure, as has been proposed for other decapod crustaceans after their exposure to stressful situations (Stumpf and López Greco, 2015). Taking into account that lipid levels can be rapidly restored following a stress period (Stumpf and López Greco, 2015), the higher energetic efficiency at the optimum temperature may explain the fast accumulation of more lipid reserves in TOFs before mating and spawning. This may explain, in turn, the higher energy content in both TOF pleons and TOF cephalothoraxes as compared to those in COFs, considering that lipids are the main energy source in decapod crustaceans (Holland, 1978).

Interestingly, thermal stress had no apparent effect on egg production, with TOFs and COFs showing similar values of relative realized fecundity. However, maternal investment in yolk synthesis differed between control and transferred females, because protein content was lower in TOF eggs than in COF eggs. In crustaceans and fishes, proteins are a source of amino acids and a reservoir of materials used during the many biosynthetic activities that take place in early stages of embryogenesis. They can also be used as fuel in the final stages of development, when lipid reserves decrease (Brooks et al., 1997; García Guerrero et al., 2003). Hence, the lower protein content in TOF eggs could have led to possible deficiencies in tissue structure formation and energy use during 
Table 2

Loadings, eigenvalues, and percentage of total variance accounted for the first (PC1) and second (PC2) principal components (covariance matrix) of fatty acid composition in Neocaridina davidi females and their eggs

\begin{tabular}{|c|c|c|c|c|}
\hline \multirow[b]{3}{*}{ Fatty acid } & \multicolumn{4}{|c|}{ Principal components } \\
\hline & \multicolumn{2}{|c|}{ COFs and TOFs } & \multicolumn{2}{|c|}{ COFs and their eggs } \\
\hline & $\mathrm{PC} 1$ & $\mathrm{PC} 2$ & $\mathrm{PC} 1$ & PC2 \\
\hline $\mathrm{C} 10: 0$ & 0.0241 & -0.0385 & -0.0119 & 0.0397 \\
\hline $\mathrm{C} 12: 0$ & 0.0470 & -0.0775 & -0.0297 & 0.0594 \\
\hline $\mathrm{C} 14: 0$ & 0.0541 & -0.0771 & -0.0082 & 0.0858 \\
\hline $\mathrm{C} 14: 1$ & 0.0399 & 0.0776 & 0.0194 & 0.0407 \\
\hline $\mathrm{C} 15: 0$ & 0.0020 & 0.0182 & 0.0024 & 0.0066 \\
\hline $\mathrm{C} 15: 1$ & 0.0028 & 0.0011 & 0.0073 & 0.0138 \\
\hline $\mathrm{C} 16: 0$ & -0.5018 & -0.3010 & 0.1536 & -0.5122 \\
\hline C16:1 & -0.0288 & 0.1097 & 0.2152 & 0.1427 \\
\hline $\mathrm{C} 17: 0$ & 0.0433 & -0.0643 & -0.0735 & 0.0208 \\
\hline $\mathrm{C} 17: 1$ & 0.1481 & -0.1435 & -0.0571 & 0.2226 \\
\hline $\mathrm{C} 18: 0$ & -0.1631 & 0.0864 & 0.0174 & -0.2163 \\
\hline $\mathrm{C} 18: \ln 9 *$ & -0.5294 & 0.1682 & 0.5696 & -0.2013 \\
\hline $\mathrm{C} 18: 1 \mathrm{n} 7$ & -0.0769 & 0.1149 & 0.0345 & -0.0758 \\
\hline $\mathrm{C} 18: \ln 11$ & 0.0009 & 0.0067 & 0.0024 & 0.0066 \\
\hline $\mathrm{C} 18: 2 \mathrm{n} 6^{*}$ & -0.1388 & 0.2808 & 0.3999 & 0.1359 \\
\hline C18:3n6 & -0.0073 & 0.0081 & 0.0314 & 0.0203 \\
\hline $\mathrm{C} 18: 4 \mathrm{n} 3$ & 0.0028 & 0.0004 & 0.0013 & 0.0100 \\
\hline $\mathrm{C} 20: 1$ & 0.0259 & 0.0617 & 0.0087 & 0.0076 \\
\hline $\mathrm{C} 18: 3 \mathrm{n} 3$ & 0.0067 & -0.0335 & -0.0016 & 0.0148 \\
\hline $\mathrm{C} 21: 0$ & 0.0289 & -0.0283 & -0.0435 & 0.0000 \\
\hline $\mathrm{C} 22: 0$ & 0.1568 & 0.3223 & -0.3001 & -0.1349 \\
\hline $\mathrm{C} 20: 3 \mathrm{n} 6$ & 0.0000 & 0.0000 & 0.0020 & 0.0018 \\
\hline $\mathrm{C} 22: \ln 11$ & 0.0454 & 0.0793 & -0.0048 & 0.0105 \\
\hline $\mathrm{C} 22: \ln 9$ & 0.0476 & 0.0130 & -0.5170 & -0.4487 \\
\hline $\mathrm{C} 24: 0$ & 0.0000 & 0.0000 & 0.0056 & 0.0049 \\
\hline C20:4n6 & 0.1100 & 0.1412 & -0.0420 & 0.0529 \\
\hline C20:5n3 (EPA) & 0.0824 & -0.7662 & -0.1652 & 0.1538 \\
\hline $\mathrm{C} 22: 6 \mathrm{n} 3$ (DHA) & 0.5786 & 0.0433 & -0.2112 & 0.5426 \\
\hline Eigenvalues & 27.8847 & 4.8579 & 119.0210 & 12.4148 \\
\hline$\%$ Variance & 84.5720 & 14.7340 & 90.5540 & 9.4456 \\
\hline
\end{tabular}

$\mathrm{COF}$, control ovigerous females, females maintained at $28^{\circ} \mathrm{C} \pm 1{ }^{\circ} \mathrm{C}$ from hatching to spawning; DHA, docosahexaenoic acid; EPA, eicosapentaenoic acid; TOF, transferred origerous females, females maintained at $33{ }^{\circ} \mathrm{C} \pm 1{ }^{\circ} \mathrm{C}$ from hatching and transferred to $28^{\circ} \mathrm{C} \pm 1{ }^{\circ} \mathrm{C}$ after a 200 -day period.

* Cis and trans configurations.

embryonic development. Future studies are necessary to determine whether the apparent physiological recovery of transferred females has no consequences for the quality of embryos and hatched juveniles. Despite the biochemical difference in proteins, total energy content did not vary between COF and TOF eggs. This was probably a consequence of their similar lipid concentration, because lipids are the main yolk component in N. davidi eggs (Tropea and López Greco, 2015) and also the main energy source for the developing embryo (Herring, 1974). TOF eggs had a wet weight slightly higher than and a volume similar to that of COF eggs, regardless of their lower protein content. This unexpected result may be attributed to higher post-spawning hydration of TOF eggs or differences in nutrient composition. The analysis in future studies of lipid and amino acid profiles, along with water content in each group of eggs, may shed some light on this issue.

With respect to FA profiles, a clear dominance of SFAs and MUFAs over PUFAs and HUFAs was found for both COFs and TOFs, a logical result when considering that C14:0, C16:0, C18:1, and C18:0 are the main FAs in the ovary and hepatopancreas of decapod crustaceans. The main function of these FAs is to provide energy (Gonzalez Baro and Pollero, 1988; Catacutan, 1991; Ying et al., 2006). The pleon had more C16:0 and C18:1n9 than the cephalothorax, both in COFs and in TOFs. These FAs had been described as typical in other freshwater and marine crustaceans, but with no distinction in their location between the pleon and the cephalothorax (Clarke, 1979; Farkas, 1979; Bragagnolo and RodriguezAmaya, 2001).

On the other hand, HUFAs of the n6 series (C18:2n6, LIN) were more abundant than those of the $n 3$ series (EPA and DHA), which coincides with previous results on other freshwater decapods (Chanmungam et al., 1983). Marine crustaceans usually show the opposite relationship between n6 and n3 series and have higher levels of EPA and DHA than freshwater decapods (Gonzalez Baro and Pollero, 1988). This suggests that the function of EPA and DHA may be replaced in the latter by n6 PUFAs, such as LIN (Cheng et al., 1998), whose essential role has been demonstrated in juveniles (Reigh and Stickney, 1989; D'Abramo and Sheen, 1993). Although not predominant, EPA and DHA still stand out in the FA profile of ovigerous females due to their relative abundance. In particular, DHA levels were higher in the cephalothorax than in the pleon, indicating that DHA may be stored in the hepatopancreas, probably as a source of metabolic energy. It is unlikely that DHA reserves were then transferred to maturing oocytes in the studied species, because their levels were very low in COF eggs. DHA was found to be the most used FA during embryonic development of the freshwater prawn Macrobrachium rosenbergii (de Man, 1879), with $62.5 \%$ of its initial content being consumed as an energy source (Clarke et al., 1990; Cavalli et al., 1999). Moreover, DHA was proposed to play an important role in hatching success and nervous system formation in embryos of marine decapods; it also functions as a structural component of cell membranes (Xu et al., 1994; Wen et al., 2002; Chang et al., 2017). Considering the high levels of LIN in COF eggs, it is possible that $N$. davidi females derived great amounts of this FA during vitellogenesis for its use as a DHA precursor by embryos. The fact that LIN has been proposed to act as a precursor of n6 FAs in $M$. rosenbergii eggs (Reigh and Stickney, 1989) and the fact that freshwater fishes are able to elongate 18-carbon omega-3 and omega-6 FAs to 20- and 22-carbon FAs (Bell and Tocher, 2009) support our hypothesis.

Although the transfer treatment affected the percentage of some specific FAs (e.g., EPA), the relative abundance of total SFAs, MUFAs, and PUFAs was similar between COFs and TOFs. This suggests that the effect of high temperature on lipid profile, if any, was almost completely reversed after 


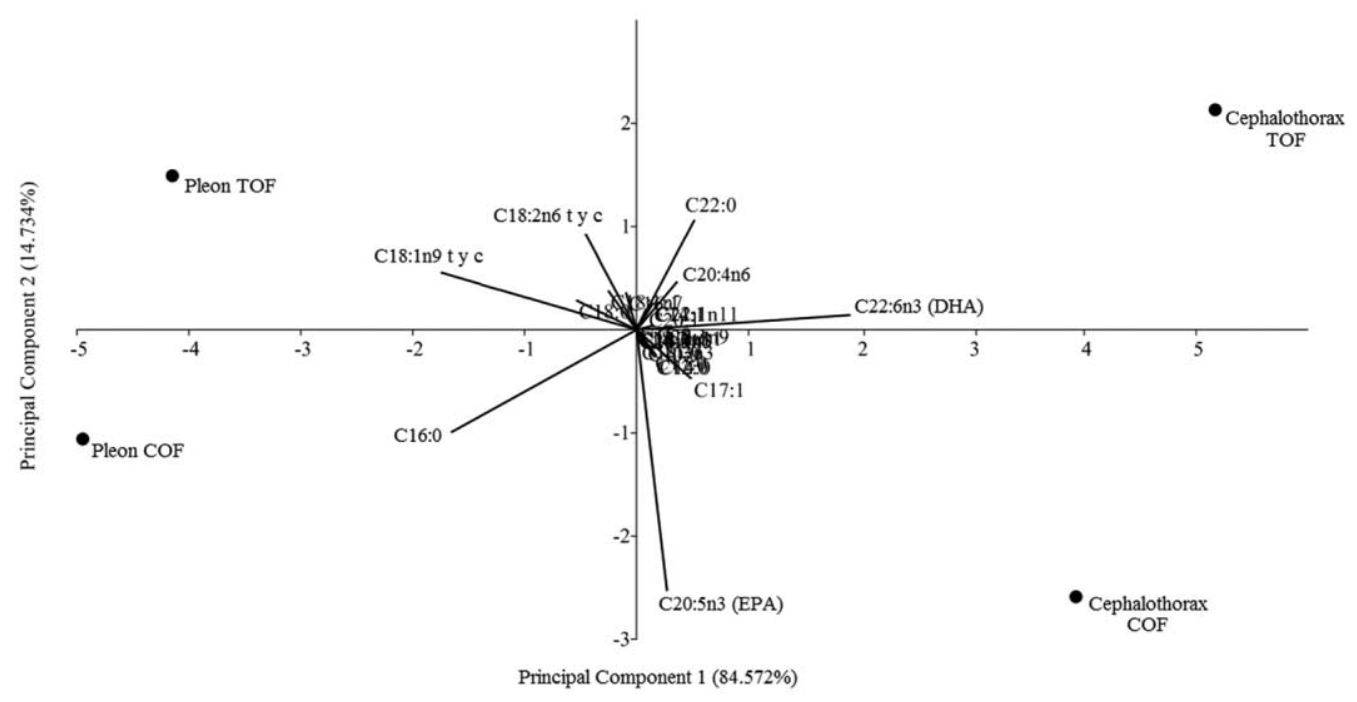

Figure 6. Principal components analysis biplot of fatty acid composition in the pleon and cephalothorax of Neocaridina davidi ovigerous females. The first and second principal components were plotted in an $x-y$ plane and accounted for $84.6 \%$ and $14.7 \%$, respectively, of total variance. COF, control ovigerous females, females maintained at $28^{\circ} \mathrm{C} \pm 1{ }^{\circ} \mathrm{C}$ from hatching to spawning; DHA, docosahexaenoic acid; EPA, eicosapentaenoic acid; TOF, transferred ovigerous females, females maintained at $33^{\circ} \mathrm{C} \pm 1{ }^{\circ} \mathrm{C}$ from hatching and transferred to $28^{\circ} \mathrm{C} \pm$ $1{ }^{\circ} \mathrm{C}$ after a 200 -day period.

females were moved to the optimum temperature. The high percentage of palmitic acid (C16:0), oleic acid (C18:1n9), erucic acid (C22:1n9), and LIN (C18:2n6) found in ovigerous females (independent of temperature regime and body part) clearly matches their relative abundance in the diet provided to females (see Table 1). Therefore, it seems that these FAs were mostly incorporated with food and poorly synthesized by females, particularly in the case of LIN, which was the main component $(35 \%)$ of the diet. This is an essential PUFA in most aquatic animals that, consequently, cannot be synthesized de novo (D'Abramo and Sheen, 1993).

As in ovigerous females, SFAs and MUFAs were more abundant than PUFAs and HUFAs in COF eggs, where they may also serve as a source of energy during embryogenesis (Clarke et al., 1990). The most abundant FAs in N. davidi eggs were palmitic acid, oleic acid, and LIN. Palmitic and

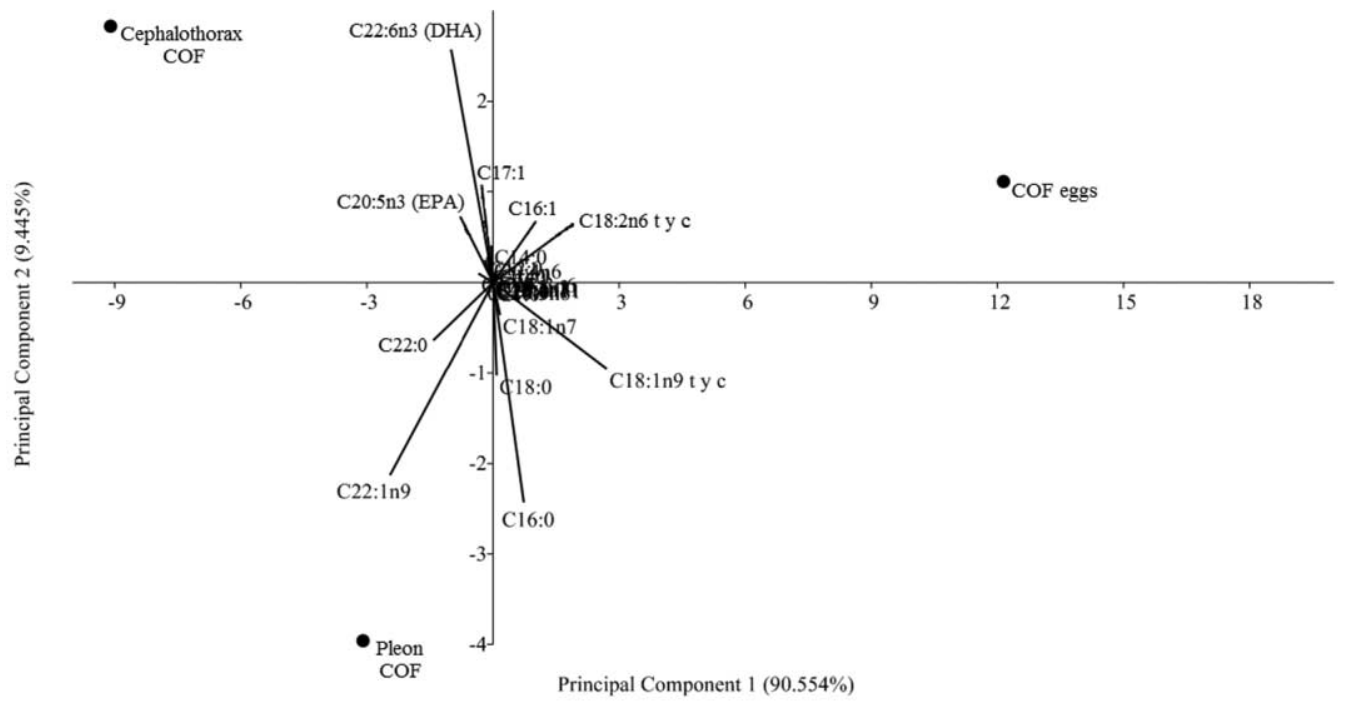

Figure 7. Principal components analysis biplot of fatty acid composition in the cephalothorax and pleon of Neocaridina davidi ovigerous females and in their eggs. The first and second principal components were plotted in an $x-y$ plane and accounted for $90.6 \%$ and $9.5 \%$, respectively, of total variance. COF, control ovigerous females, females maintained at $28{ }^{\circ} \mathrm{C} \pm 1{ }^{\circ} \mathrm{C}$ from hatching to spawning; DHA, docosahexaenoic acid; EPA, eicosapentaenoic acid. 
oleic acid predominance is a general trend in eggs of decapod shrimps with indirect development (Clarke et al., 1990; Graeve and Wehrtmann, 2003; Chang et al., 2017). Of the above-mentioned species, high levels of LIN were reported only in newly extruded eggs of the crab Eriocheir sinensis (Chang et al., 2017). Although these FAs have been proposed to act as fuel during embryonic development (Clarke et al., 1990), their function has not yet been clearly determined.

In summary, the present results show a clear negative effect of high temperature on reserve mobilization to the maturing ovary in an aquatic invertebrate with direct development, inhibiting ovarian maturation and spawning. This effect was rapidly and almost completely reversed after females were transferred to the optimum temperature, with the consequent production of eggs resembling that of control females in both number and size. Moreover, the mobilization of lipids (the main yolk component and energy source for embryonic development) and glycogen to the maturing oocytes was not altered. Even though high temperature had consequences on maternal provisioning, it did not affect the storage of biochemical reserves in female tissues. The present results partially support our initial hypothesis (stating that a temperature higher than the optimum affects female biochemical composition and nutrient transfer to maturing oocytes) and provide valuable information on reserve allocation to reproduction under environmentally stressful conditions.

\section{Acknowledgments}

This study is part of the undergraduate thesis by SB (University of Buenos Aires), which was funded by a scholarship from Consejo Interuniversitario Nacional (CIN), Argentina. LSLG is grateful to Agencia Nacional de Promoción Científica y Tecnológica (PICT, 2012, project 1333), Consejo Nacional de Investigaciones Científicas y Técnicas (CONICET, Proyectos de Investigación Plurianuales [PIP] 2012-2014, project 112201101-00212), and Universidad de Buenos Aires (UBACYT, 2014-2017, project 20020130100186BA) for financial support. BT was partially funded by CONICET (PIP 112-2008 0100815, PIP 112-20110100892). All the authors are grateful to Dr. Agueda Massa for logistical support (Instituto Nacional de Desarrollo Pesquero [INIDEP], Argentina).

\section{Literature Cited}

Anger, K. 2001. The Biology of Decapod Crustacean Larvae. Balkema, Lisse, The Netherlands.

Bell, M. V., and D. R. Tocher. 2009. Biosynthesis of polyunsaturated fatty acids in aquatic ecosystems: general pathways and new directions. Pp. 211-236 in Lipids in Aquatic Ecosystems, M. T. Arts, M. T. Brett, and M. Kainz, eds. Springer, New York.

Besnard, J. I. 1988. Étude des constituants lipidiques dans la gonade femelle et des larves de Pecten maximus L. Thèse de Docteur en Biologie, Universitè de Caen, 154 pp.
Bradford, M. 1976. A rapid and sensitive method for the quantitation of microgram quantities of protein utilizing the principle of protein-dye binding. Anal. Biochem. 72: 248-253.

Bragagnolo, N., and D. B. Rodriguez-Amaya. 2001. Total lipid, cholesterol, and fatty acids of farmed freshwater prawn (Macrobrachium rosenbergii) and wild marine shrimp (Penaeus brasiliensis, Penaeus schimitti, Xiphopenaeus kroyeri). J. Food Compos. Anal. 14: 359-369.

Brooks, S., C. R. Tyler, and J. P. Sumpter. 1997. Egg quality in fish: What makes a good egg? Rev. Fish Biol. Fish. 7: 387-416.

Buckup, L., B. K. Dutra, F. P. Ribarcki, F. A. Fernandes, C. K. Noro, G. T. Oliveira, and A. S. Vinagre. 2008. Seasonal variations in the biochemical composition of the crayfish Parastacus defossus (Crustacea, Decapoda) in its natural environment. Comp. Biochem. Physiol. A Mol. Integr. Physiol. 149: 59-67.

Cahu, C. L., G. Cuzon, and P. Quazuguel. 1995. Effect of highly unsaturated fatty acids, tocopherol and ascorbic acid in broodstock diet on egg composition and development of Penaeusindicus. Comp. Biochem. Physiol. A Physiol. 112: 417-424.

Calow, P. 1989. Proximate and ultimate responses to stress in biological systems. Biol. J. Linn. Soc. 37: 173-181.

Catacutan, M. R. 1991. Growth and fatty acid composition of Penaeus monodon juveniles fed various lipids. Isr. J. Aquacult. 43: 47-56.

Cavalli, R. O., P. Lavens, and P. Sorgeloos. 1999. Performance of Macrobrachium rosenbergii broodstock fed diets with different fatty acid composition. Aquaculture 179: 387-402.

Cavalli, R. O., M. Tamtin, P. Lavens, and P. Sorgeloos. 2001. Variations in lipid classes and fatty acid content in tissues of wild Macrobrachium rosenbergii (de Man) females during maturation. Aquaculture 193: 311-324.

Chang, A., C. Wu, Y. Cheng, C. Zeng, and Z. Yu. 2017. Reproductive performance, offspring quality, proximate and fatty acid composition of normal and precocious Chinese mitten crab Eriocheir sinensis. Aquaculture 469: 137-143.

Chanmungam, P., J. Donovan, C. J. Wheeler, and D. H. Hwang. 1983. Differences in the lipid composition of freshwater prawn Macrobrachium rosenbergii and marine shrimp. J. Food Sci. 48: 14401443.

Cheng, Y. X., N. S. Du, and W. Lai. 1998. Lipid composition in hepatopancreas of Chinese mitten crab Eriocheir sinensis at different stages. Acta Zool. Sin. 44: 420-429.

Childress, J. J., D. L. Cowles, J. A. Favuzzi, and T. J. Mickel. 1990. Metabolic rates of benthic deep-sea decapod crustaceans decline with increasing depth primarily due to the decline in temperature. DeepSea Res. 37: 929-949.

Clarke, A. 1979. Lipid content and composition of the pink shrimp, Pandalus montagui (Leach) (Crustacea: Decapoda). J. Exp. Mar. Biol. Ecol. 38: 1-17.

Clarke, A. 1993. Egg size and egg composition in polar shrimps (Caridea: Decapoda). J. Exp. Mar. Biol. Ecol. 168: 189-203.

Clarke, A., J. H. Brown, and L. J. Holmes. 1990. The biochemical composition of eggs from Macrobrachium rosenbergii in relation to embryonic development. Comp. Biochem. Physiol. B Comp. Biochem. 96: 505-511.

D'Abramo, L. R., and S. S. Sheen. 1993. Polyunsaturated fatty acid nutrition in juvenile freshwater prawn Macrobrachium rosenbergii. Aquaculture 115: 63-86.

Di Rienzo, J. A., A. W. Guzmán, and F. Casanoves. 2002. A multiplecomparisons method based on the distribution of the root node distance of a binary tree. J. Agric. Biol. Environ. Stat. 7: 129-142.

Dowd, M. K. 2012. Identification of the unsaturated heptadecyl fatty acids in the seed oils of Thespesia populnea and Gossypium hirsutum. J. Am. Oil Chem. Soc. 89: 1599-1609.

Dridi, S., M. S. Romdhane, and M. Elcafsi. 2007. Seasonal variation in weight and biochemical composition of the Pacific oyster, Crassostrea 
gigas in relation to the gametogenic cycle and environmental conditions of the Bizert lagoon, Tunisia. Aquaculture 263: 238-248.

Farkas, T. 1979. Adaptation of fatty acid compositions to temperature-a study on planktonic crustaceans. Comp. Biochem. Physiol. B Comp. Biochem. 64: 71-76.

Folch, J., M. Lees, and G. H. S. Stanley. 1957. A simple method for isolation and purification of total lipids from animal tissues. J. Biol. Chem. 226: 497-509.

Gabbot, P. A., and B. L. Bayne. 1973. Biochemical effects of temperature and nutritive stress on Mytilus edulis L. J. Mar. Biol. Assoc. U.K. 53: 269-286.

García, F., M. Gonzalez-Baro, and R. Pollero. 2002. Transfer of lipids between hemolymph and hepatopancreas in the shrimp Macrobrachium borellii. Lipids 37: 581-585.

García Guerrero, M., I. S. Racotta, and H. Villarreal. 2003. Variation in lipid, protein, and carbohydrate content during the embryonic development of the crayfish Cherax quadricarinatus (Decapoda: Parastacidae). J. Crustac. Biol. 23: 1-6.

Gardner, C. 2001. Composition of eggs in relation to embryonic development and female size in giant crabs Pseudocarcinus gigas (Lamarck). Mar. Freshw. Res. 52: 333-338.

Gonzalez-Baro, M. R., and R. J. Pollero. 1988. Lipid characterization and distribution among tissues of the freshwater crustacean Macrobrachium borellii during annual cycle. Comp. Biochem. Physiol. B Comp. Biochem. 91: 711-715.

Graeve, M., and I. S. Wehrtmann. 2003. Lipid and fatty acid composition of Antarctic shrimp eggs (Decapoda: Caridea). Polar Biol. 26: 55-61.

Hammer, O., D. A. T. Harper, and P. D. Ryan. 2001. PASTPAlaeontological STatistics. [Online]. Available: http://www.uv.es / pardomv/pe/2001_1/past/pastprog/past.pdf [2018, May 15].

Harrison, K. E. 1990. The role of nutrition in maturation, reproduction and embryonic development of decapod crustaceans: a review. J. Shellfish Res. 9: 1-28.

Helm, M. M., D. L. Holland, and R. R. Stephenson. 1973. The effect of supplementary algal feeding of a hatchery breeding stock of Ostrea edulis L. on larval vigour. J. Mar. Biol. Assoc. U.K. 53: 673-684.

Herring, P. J. 1973. Depth distribution of the carotenoid pigments and lipids of some oceanic animals. 2. Decapod crustaceans. J. Mar. Biol. Assoc. U.K. 53: 539-562.

Herring, P. J. 1974. Size, density and lipid content of some decapod eggs. Deep-Sea Res. 21: 91-94.

Holcomb, M., J. G. Cloud, J. Woolsey, and R. L. Ingermann. 2004. Oxygen consumption in unfertilized salmonid eggs: an indicator of egg quality? Comp. Biochem. Physiol. A Mol. Integr. Physiol. 138: 349-354.

Holland, D. L. 1978. Lipid reserves and energy metabolism in the larvae of benthic marine invertebrates. Pp. 85-123 in Biochemical and Biophysical Perspectives in Marine Biology, D. C. Malins, ed. Academic Press, Seattle.

Kooijman, S. A. L. M. 2010. Dynamic Energy and Mass Budgets in Biological Systems. Cambridge University Press, Cambridge.

Martínez, G., C. Aguilera, and L. Mettifogo. 2000a. Interactive effects of diet and temperature on reproductive conditioning of Argopecten purpuratus broodstock. Aquaculture 183: 149-159.

Martínez, G., K. Brokordt, C. Aguilera, V. Soto, and H. Guderley. 2000b. Effect of diet and temperature upon muscle metabolic capacities and biochemical composition of gonad and muscle in Argopecten purpuratus Lamarck 1819. J. Exp. Mar. Biol. Ecol. 247: 29-49.

Muriana, F. J. G., V. Ruiz-Gutierrez, M. L. Gallardo-Guerrero, and M. I. Minguez Mosquera. 1993. A study of the lipids and carotenoprotein in the prawn Penaeus japonicus. J. Biochem. 114: 223-229.

Palacios, E., A. M. Ibarra, and I. S. Racotta. 2000. Tissue biochemical composition in relation to multiple spawning in wild and pond-reared Penaeus vannamei broodstock. Aquaculture 185: 353-371.
Reigh, R. C., and R. R. Stickney. 1989. Effect of purified dietary fatty acids on the fatty acid composition of freshwater shrimp, Macrobrachium rosenbergii. Aquaculture 77: 157-174.

Reynolds, J. 2002. Growth and reproduction. Pp. 152-184 in Biology of Freshwater Crayfish, M. Holdich, ed. Blackwell Science, Oxford.

Rodríguez-González, H., A. Hernández-Llamas, H. Villarreal, P. E. Saucedo, M. García-Ulloa, and C. Rodríguez-Jaramillo. 2006. Gonadal development and biochemical composition of female crayfish Cherax quadricarinatus (Decapoda: Parastacidae) in relation to the gonadosomatic index at first maturation. Aquaculture 254: 637-645.

Rosa, R., and M. L. Nunes. 2003. Tissue biochemical composition in relation to the reproductive cycle of deep-sea decapod Aristeus antennatus in the south Portuguese coast. J. Mar. Biol. Assoc. U.K. 83: 963-970.

Rosa, R., R. Calado, A. M. Andrade, L. Narciso, and M. L. Nunes. 2005. Changes in amino acids and lipids during embryogenesis of European lobster, Homarus gammarus (Crustacea: Decapoda). Comp. Biochem. Physiol. B Biochem. Mol. Biol. 140: 241-249.

Ruiz, C., D. Martínez, G. Mosquera, M. Abad, and J. L. Sánchez. 1992. Seasonal variations in condition, reproductive activity and biochemical composition of the flat oyster, Ostrea edulis, from San Cibran, Galicia, Spain. Mar. Biol. 112: 67-74.

Stumpf, L., and L. S. López Greco. 2015. Compensatory growth in juveniles of freshwater redclaw crayfish Cherax quadricarinatus reared at three different temperatures: hyperphagia and food efficiency as primary mechanisms. PLoS One 10: e0139372.

Thomas, C. W., B. J. Crear, and P. R. Hart. 2000. The effect of temperature on survival, growth, feeding and metabolic activity of the southern rock lobster, Jasus edwardsii. Aquaculture 185: 73-84.

Tidwell, J. H., S. D. Coyle, J. Evans, C. Weibel, J. McKinney, K. Dodson, and H. Jones. 1999. Effect of culture temperature on growth, survival, and biochemical composition of yellow perch Perca fiavescens. J. World Aquac. Soc. 30: 324-330.

Tropea, C., and L. S. López Greco. 2015. Female growth and offspring quality over successive spawnings in a caridean shrimp Neocaridina davidi (Decapoda, Atyidae) with direct development. Biol. Bull. 229: 243-254.

Tropea, C., L. Stumpf, and L. S. Lopez Greco. 2015. Effect of temperature on biochemical composition, growth and reproduction of the ornamental red cherry shrimp Neocaridina heteropoda heteropoda (Decapoda, Caridea). PLoS One 10: e0119468.

Van Handel, E. 1965. Estimation of glycogen in small amount soft tissue. Anal. Biochem. 11: 256-265.

Vogt, G., V. Storch, E. T. Quinitio, and F. P. Pascual. 1985. Midgut gland as monitor organ for the nutritional value of diets in Penaeus monodon (Decapoda). Aquaculture 48: 1-12.

Wen, X. B., L. Q. Chen, Z. L. Zhou, C. X. Ai, and G. Y. Deng. 2002. Reproduction response of Chinese mitten-handed crab (Eriocheir sinensis) fed different sources of dietary lipid. Comp. Biochem. Physiol. A Mol. Integr. Physiol. 131: 675-681.

Wickins, J. F., T. W. Beard, and A. R. Child. 1995. Maximizing lobster, Homarus gammarus egg and larval viability. Aquac. Res. 26: 379-392.

Winberg, G. G. 1971. Methods for the Estimation of Production of Aquatic Animals. Academic Press, London.

Wouters, R., L. Gómez, P. Lavens, and L. Calderón. 1999. Feeding enriched artemia biomass to Penaeus vannamei broodstock: its effect on reproductive performance and larval quality. J. Shellfish Res. 18: 651656.

Xu, X. L., W. J. Ji, J. D. Castell, and R. K. O'Dor. $1994 . \quad$ Influence of dietary lipid sources on fecundity, egg hatchability and fatty acid composition of Chinese prawn (Penaeus chinensis) broodstock. Aquaculture 119: 359-370.

Ying, X. P., W. X. Yang, and Y. P. Zhang. 2006. Comparative studies on fatty acid composition of the ovaries and hepatopancreas at different physiological stages of the Chinese mitten crab. Aquaculture 256: 617-623. 